\title{
POSTERS
}

\section{Black Theology Papers Project}

Andrea C. White, Union Theological Seminary

Adam Clark, Xavier University

\begin{abstract}
The Black Theology Papers Project is an open access journal that preserves and promotes the intellectual heritage of Black theology. The journal strives to advance the field by publishing a yearly issue of the proceedings of the Black Theology Unit of the American Academy of Religion's annual meeting. The Black Theology Papers Project is supported by Columbia University Libraries.
\end{abstract}

The Black Theology Papers Project aspires to be a premiere scholarly and teaching resource for students and faculty interested in emerging scholarship and cutting-edge research in the field of Black theology. The journal was launched November 2019 both in honor of the 50th anniversary celebration of Dr. James H. Cone's publication of his groundbreaking work, Black Theology and Black Power (Orbis Books, 1969) and to commemorate four hundred years since the enslavement of Africans in the Americas.

The Black Theology Papers Project-an online journal supported by Columbia University Libraries-serves as a repository to preserve and promote the intellectual heritage of Black theology. The journal features papers presented by the Black Theology Unit of the American Academy of Religion. The journal publishes an annual issue of the proceedings of the AAR Black Theology Unit.

Editors are Adam Clark, Associate Professor of Theology at Xavier University, Andrea C. White, Associate Professor of Theology and Culture at Union Theological Seminary, and Josef Sorett, Associate 
Professor of Religion and African American and African Diaspora Studies at Columbia University.

Papers are reviewed and selected for presentation and publication by the AAR Black Theology Unit Chairs and Steering Committee and the editors of the Black Theology Papers Project.

As an open access journal, all content in the Black Theology Papers Project is freely available without charge to users or their institution. Users are allowed to read, download, copy, distribute, print, search, or link to the full texts of the articles in this journal without seeking prior permission from the publisher or the author. Authors retain their copyright and agree to license their articles with a Creative Commons "Attribution" (CC-BY) License.

The Black Theology Papers Project is indexed in:

- Directory of Open Access Journals (DOAJ)

- Google Scholar

- Columbia University's Academic Commons

Support and organization of the Atla poster presentation was provided by Matthew Baker, Head of the Burke Library at Union Theological Seminary, Columbia University Libraries. Editorial assistance was provided by Heather Ketchum, PhD student at Princeton Theological Seminary. 